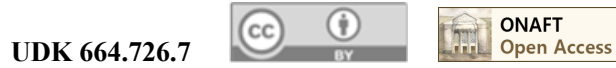

DOI https://doi.org.

L. Soldatenko, HhD. tech. Sciences, associate Professor, E-mail: leonid541247@gmail.com ORCID 0000-0003-4423-088X Researcher ID: U-7423-2017

A. Shipko, Post-graduate student,E-mail: shipko.arkadiy@gmail.com ORCID 0000-0002-5665-1748 Researcher ID: M-1249-2016

I. Shipko, HhD. tech. Sciences, associate Professor, E-mail: shipkoigor@gmail.com ORCID 0000-0003-4148-397X, Researcher ID: U-3829-2017

Odessa National Academy of Food Technologies, 112, Kanatna Str., Odessa, 65039, Ukraine, +380487124113

\title{
IMPROVING THE DESIGN OF THE BRUSH MACHINE FOR GRAIN
}

\begin{abstract}
Abstrakt
The quality of the finished products of flour mills largely depends on the efficiency of grain cleaning equipment, in particular, on those intended for cleaning the grain surface from dense deposits of organic and mineral dust. In modern conditions of an acute shortage of household drinking water, when the use of washing and washer-hulling machines becomes impractical or completely impossible, the role of equipment for dry processing of grain surfaces scouring and brushing machines - is significantly increasing. Scouring machines separate high-ash dust deposits from the surface of the grain, separate the embryo and bangs, destroy clods of earth commensurate with the grain, and also lead to partial peeling of fruit shells. But they cannot remove dust and microorganisms from the groove of the weevil. This task - in the absence of washing and washer-hulling machines - is solved exclusively by brushing machines. They remove dust and microorganisms from the groove, the remains of dust, embryos and bangs, fruit shells torn by the peeling machines, and reduce the ash content of the refined grain by $0.02 \ldots 0.03 \%$. And although the efficiency of the brushing machines is less than the efficiency of the scourers, they are irreplaceable at the final stages of cleaning the grain surface. The decisive influence on the efficiency of the operation of brushing machines is created by the technical condition of the working bodies and the size of the working gap between the brush rotor and the brush deck, which should be 4 ... $8 \mathrm{~mm}$. However, over time, the brush surfaces of the rotor and deck will wear out, become dirty, clogged with dust and deform - the bristles get a slope and the working gap increases. In many respects, this is corrected by regulation with a special adjusting mechanism. But its capabilities are limited, and the longer the brush is used, the more often the regulation is required and the less effective it becomes. Specialists from many countries are engaged in the improvement of brush machines: Russia, Switzerland, Poland, etc. An overview of the designs and functional diagrams of machines of various companies, as well as inventions and patents in this area, can contribute to the improvement of the A1-БЩM-12 brush machine, which is most often used in production lines of domestic enterprises.

Invention "Brush machine for cleaning grain surface" for copyright certificate No. 459248 is just about the equipment for cleaning wheat and rye. The aim of the invention is to improve the efficiency of processing the surface of the grain by lengthening the path of its friction along the working surfaces of the rotor and the deck and continuous extraction of particles separated from the grain over the entire surface of the deck. For this, the proposed machine has a deck, which consists of a set of cylindrical brush rollers that rotate in mutually opposite directions. Externally, the deck is covered by a sieve shell, which can be made corrugated to increase the grain cleaning effect. The working area is formed by a rotary brush rotor and a brush-roller deck. Rollers of odd numbers rotate in the direction opposite to the direction of rotation of the rotor at half the speed, and rollers of paired numbers rotate at the same speed as odd numbers, but in the same direction as the rotor. Grain in the working area goes through a complex zigzag path, after which it is blown with air and goes outside. To compensate for the wear of the brushes and regulate the size of the working gap, the axes of the rollers on both sides are installed in the radial grooves of the two fixed sidewalls and simultaneously in the inclined grooves of the rotary plates mounted on the cylindrical protrusions of these sidewalls. Since the total surface area of the brush rollers is almost 4 times larger than the deck area of the A1-БЩM-12 machine, the specific load on the surface of the rollers is significantly reduced, which guarantees a longer and more efficient operation of the brush machine.
\end{abstract}

Key words: grain brushing machine; ash content of grain; groove; brush rotor; brush rollers; working clearance.

\section{Introduction}

The quality of the finished products of flour mills largely depends on the efficiency of grain cleaning equipment, in particular, on those intended for cleaning the grain surface from dense deposits of organic and mineral dust. In modern conditions of an acute shortage of household drinking water, when the use of washing and washer-hulling machines becomes impractical or completely impossible, the role of equipment for dry processing of grain surfaces - scouring and brushing machines - is significantly increasing.

Scouring machines separate high-ash dust deposits from the grain surface, separate the embryo and bang, destroy clods of earth, commensurate with the grain, and also lead to partial peeling of fruit shells. But they cannot remove dust and microorganisms from the 
groove of the weevil. This task - in the absence of washing and washer-hulling machines - is solved exclusively by brushing machines.

They remove dust and microorganisms from the groove, the remains of dust, embryos and bangs, fruit shells torn by the peeling machines, and reduce the ash content of the refined grain by $0.02 \ldots 0.03 \%$. And although the efficiency of the brushing machines is less than the efficiency of the scouring machines, they are irreplaceable at the final stages of cleaning the grain surface. The decisive influence on the efficiency of the operation of brushing machines is created by the size of the working gap between the brush rotor and the brush deck, which should be $4 \ldots 8 \mathrm{~mm}$.

However, over time, the brush surfaces of the rotor and deck will wear out, become dirty, clogged with dust and deform - the bristles get a slope and the working gap increases. In many respects, this is corrected by regulation with a special adjusting mechanism. But its possibilities are limited, moreover, the further, the more often and less effective regulation becomes. Specialists from many countries are engaged in the improvement of brush machines: Russia, Switzerland, Poland, etc. An overview of the designs and functional diagrams of machines of various companies, as well as inventions and patents in this area, can contribute to the modernization of these machines in order to increase their efficiency and operational reliability.

Brush machines A1-БЩМ-12 are installed at the third stage of grain preparation for high-quality milling of wheat grain [1], where the final cleaning is carried out - ash content reduction in the second-pass scraper machines with an abrasive surface, secondary processing in air-sieve separators and stone pickers, "Cold" conditioning, after which the grain is processed in brushing machines in order to more thoroughly clean it from highash particles of organic and mineral dust, remnants of the embryo and bangs, torn fruit membranes, followed by passing through an aspiration column or aspirator. The raw material for the A1-БЩМ-12 brushing machine is wheat and rye grain, which was processed in the previous machines of the production line of the grain cleaning department of the flour mill, including in the second-pass scouring machines.

Wheat and rye kernels have an elongated shape, which is ovoid, oval and barrel-shaped. The most common grain is oval and ovoid. The convex side of the grain is called the back, and the opposite is the abdominal, along which there is a groove of various depths. The groove is narrow, medium and wide in width, and shallow, medium and deep in depth (when the base of the groove is located deeper than the center of the grain).

The structure of the rye grain is very close to the grain of wheat. By shape, weeds are distinguished wide, long, narrow, long, wide, short, and narrow, short, with a fairly deep groove. It is in the groove of the grain that dust particles can remain that cannot be removed in the scouring machines. At the same time, this dust increases the ash content of the grain and the flour produced. Mineral dust in flour creates a crunchy sensation during chewing, not allowed by the standard. Therefore, the role of brushing machines in preparing grain for grinding can hardly be overestimated.
Raw materials entering the brushing machines are pre-processed in air sieve separators, triers, stone separators, magnetic separators and scouring machines. All this contributes to the preservation of the brush working bodies from wear, but all the same, over time, the brush surfaces become dirty, deformed, worn out and lose the ability to perform the intended functions with the required efficiency during the entire period of operation. Therefore, the elimination of this drawback is an urgent task that must be solved in this work.

The A1-БЩМ-12 machine [2] performs the following operations: uniform distribution of the initial grain mixture along the entire length of the brush working bodies; additional cleaning of grain from metalmagnetic impurities; preliminary blowing of the grain mixture with air flow; intensive processing of the grain layer in the working gap between the rotating brush rotor and the stationary segment brush deck; final blowing of the grain mass at the exit from the working area with an air stream operating on the counter-current principle; removal of dust and other aerodynamically light particles from the machine - products of grain processing; evacuation of cleaned grain leaving the working area by gravity through two collecting and output funnels.

The grain enters the working area formed by a rotating brush rotor and a stationary segment deck, pivotally fixed and connected to a worm-screw regulator of the working gap size, which from the product outlet should be equal to $2 \ldots 3 \mathrm{~mm}$ to the brush pile. This corresponds to the position of the pointer scale in $1 \ldots 1.5$ divisions. The wear and deformation of the bristles of the brushes accompanying the operation of the machine require periodic adjustment of the size of the working gap, focusing on the quality of the processed products. After reaching division 16 on the pointer scale, the brush tools must be replaced. It should be recalled that one of the reasons for the excessive intensification of brush wear is the pressing of the deck against the brush rotor. This is considered unacceptable and should be well known to the machine shop personnel. Normal and efficient operation of the brushing machine is possible only if the initial product is evenly distributed along the length of the working gap, which is provided by the distributor. To do this, it must be in good condition and adjusted, otherwise the uneven distribution of grain leads to uneven wear of the brushes, which in turn creates an uneven working gap and adversely affects the efficiency of the brush machine. Therefore, the technical condition of the feederdistributor, its valves, adjustment of the position of the counterbalance levers are the object of constant attention from the maintenance personnel. It is equally important to constantly monitor the technical condition and tension of the V-belt transmission belts of the brush rotor drive, preventing belts from slipping and reducing the rotor speed.

The efficiency of the operation of brushing machines is assessed by the coefficient of reducing the ash content of the grain

$$
\Delta \mathrm{Z}=\mathrm{Z}_{1}-\mathrm{Z}_{2}, \%
$$

where $Z_{1}$ and $Z_{2}$ ash content of the original grain and grain after processing in a brush machine, $\%$. 


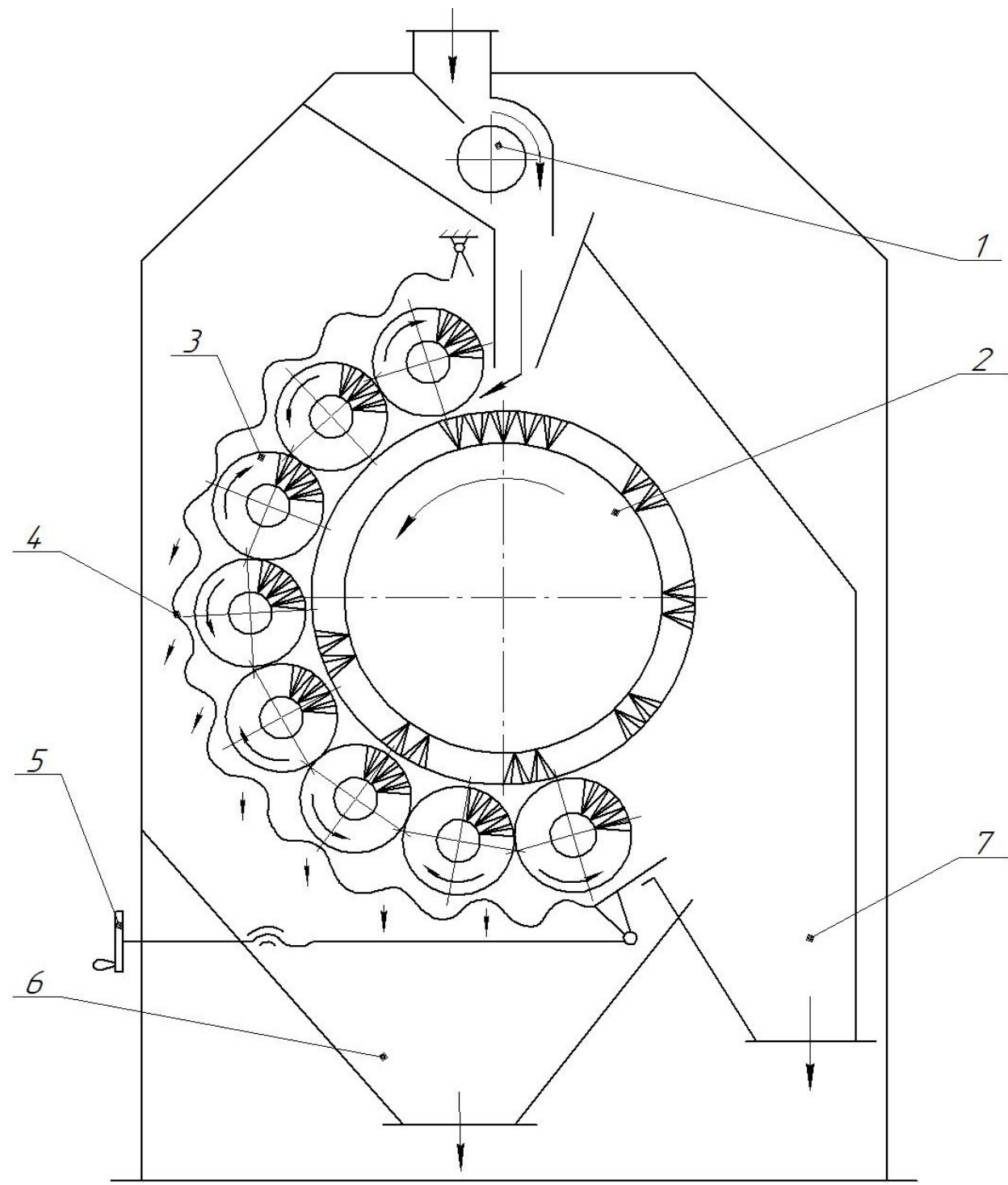

Fig. 1. Scheme of a brush machine for cleaning the surface of grain according to the invention by Author witness No. 459248: 1- receiving and distribution device; 2-brush rotor; 3-brush roller deck; 4-corrugated sieve surface; 5-regulator of the working gap between the rotor and the deck; 6 and 7 - collection and outlet pipes

During normal operation of brush machines, the ash content decreases by $0.02 \ldots 0.03 \%$, and the ash content of the generated waste is $5 \ldots 6.5 \%$. The brushing machines, in comparison with the rolling machines, have less influence on the efficiency of cleaning the grain surface. They are used mainly for final, final cleaning. In brushing machines, under the abrasive influence of the working bodies, the surface of the weevils is polished. At the same time, a significant part of the high-ash particles that are still left on the surface of the grain are separated. In this respect, brushing machines are irreplaceable. An additional indicator of the effectiveness of the A1-БЩМ12 brushing machine is the content of normal grain in the aspiration ratio. If this factor exceeds $2 \%$, then the air speed inside the machine must be reduced, and the air consumption for aspiration must be adjusted within the envisaged limits - $3500 \mathrm{~m} 3 / \mathrm{h}$. It should be noted the peculiarities of the preparation of wheat grain during pasta grinding. In the case of mechanical transportation of durum wheat grain, at the first stage, soft peeling machines are used, and during pneumatic transportation brush machines, which provide a "softer" processing mode and a decrease in the probability of grain crushing. The durability of the brush working bodies largely depends on the effectiveness of the magnetic separator, since the presence of metal-magnetic impurities in the grain causes accelerated wear of the brushes. Therefore, periodic monitoring of the magnitude of the final magnetic induction (at least once a year) or the lifting force of the magnets and the timely cleaning of the magnets from the removed metal-magnetic particles refer to the conditions of long-term and efficient operation of the brush machine.

Brush machines А1-БЩМ-12, which is used today at the enterprises of the industry, are characterized by relatively low efficiency. This is due to a certain imperfection of the design itself, which does not provide a sufficiently long stay of the grain under the influence of the brush working bodies: with a brush rotor diameter of $0.362 \mathrm{~mm}$ and an arc length of its coverage by a deck with a central angle of about $200^{\circ}$, the product path within the working area does not exceed $0.6 \mathrm{~m}$. In addition, the durability of the brush surfaces - especially the deck is insufficient. Therefore, it is advisable to use the pro- 
posed invention "Brush machine for cleaning the surface of grain" [3], which is aimed at improving the brush deck. According to this proposal, the brushing machine (Fig. 1) consists of a receiving- distributing device 1, a brush rotor 2 , a brush deck 3 , a corrugated sieve surface 4 , a mechanism 5 for adjusting the size of the working gap, and collecting and outlet pipes 6 and 7. The machine is in operation in the following way. The initial grain mixture enters the receiving-distributing device, which distributes it evenly over the entire length of the working gap between the brush rotor and the brush deck. Since the deck rollers rotate opposite each other, the grain moves along a sinusoidal path, sequentially passing through the gap between the rotor and the roller rotating towards the rotor, and then through the gap between the screen surface and the roller, which rotates in the same direction as the rotor. With this movement of grain, the duration of processing of its surface increases, which contributes to an increase in the efficiency of separation of torn shells, dust, etc. from the grain, almost directly in the places of their formation. This possibility reduces contamination of the brush working bodies during the operation of the machine and increases their durability, which is also very important. The processed grain comes out separately from the waste, which is evacuated through nozzles 6 . The brushing machines are installed, of course, after the second pass beaters. Therefore, at the moment, torn fruit membranes remain on the surface of the grain, partially - the embryo and bangs, as well as organic and mineral dust located inside the groove on the "belly" of the caryopses. Since the ash content of the shells reaches $6 \ldots 9 \%$, and the ash content of the endosperm is $0.3 \ldots 0.6 \%$, the separation of torn shells in an amount of $0.2 \ldots 0.3 \%$ of the grain weight helps to reduce the ash content of the grain prepared for grinding. It is clear that removing bang particles, germ and dust residues will also reduce ash content. Therefore, the role of brushing machines in the grain cleaning process is quite significant, especially in the manufacture of high-grade flour.

The efficiency of the brushing machines is characterized by a decrease in ash content by $0.02 \ldots 0.03 \%$, which directly depends on the length of the path that the grain mass travels in the gap between the brush surfaces of the rotor and the deck. In the existing construction, this length Lроб is

$$
\mathrm{L}_{\mathrm{po \sigma}}=\mathrm{K} \cdot \pi \cdot Д_{\mathrm{p}},
$$

where $K=\frac{\sigma}{360^{0}} ; \alpha-$ is the angle of coverage of the rotor by the deck, which in the BShM-12 machine is $201^{0}$.Then $\mathrm{K}=201360=0.558$. Since the diameter of the rotor $-Д_{p}$ - is $362 \mathrm{~mm}$, then $\mathrm{L}_{\mathrm{po \sigma}}=0.558 \cdot 3.14 \cdot 0.362$ $=0.63 \mathrm{~m}$.

If we assume that the manufacture of the improved brush deck with six brush rollers corresponds to that shown in the functional diagram (Fig. 1), then the product path length after the upgrade

$$
L_{\mathrm{pog}}^{\mathrm{Nom}}=L_{\mathrm{pod}}+4 \pi d_{\mathrm{pori}}=0,63+4 \cdot 3.14 \cdot 0.152 \cong 2.5 \mathrm{M} \text {, }
$$

where $d_{\text {рол }}$ - is the diameter of the roller, from design considerations we will take $0.152 \mathrm{~m}$. Thus, the length of the path traversed by the product in the working environment of the modernized brush machines $\mathrm{L}_{-}$ (slave) ${ }^{\wedge} \bmod$ to the length of the path in the A1-БЩМ12 machine is: $L_{\text {pod }}^{\text {mop }}: L_{\text {pod }}=2.5: 0.63 \cong 4.0$. Since not everything in the grain will pass the path corresponding to the wavy trajectory bypassing the rollers, and only a part - approximately $50 \%$ of the total product consumption, the ratio $L_{\text {pot }}^{\text {Drot }}: L_{\text {pos }}$ will be taken equal to 2 . It can be assumed that in this case, the decrease in ash content will increase 2 times and amount to $2 \cdot(0.01 \ldots 0.03) \%=$ $(0.02 \ldots 0.06) \%$. If we assume that the absolute figures are somewhat exaggerated, then the tendency to increase efficiency is obvious anyway, which confirms the expediency of modernizing the brush machine precisely by improving its deck. Invention "Brush machine for cleaning grain surface" for the author's certificate No. 459248 solves exactly this problem, since it refers to equipment for cleaning grain in preparation for grinding, which can be used, for example, in the flour-grinding industry as part of the production lines of grain cleaning shops. The implementation of this proposal requires a number of engineering developments, namely: the development of a kinematic diagram of the drive of the brush working bodies - the rotor and rollers, as well as the design of the device for regulating the size of the working gap between the rotor and the rollers. The kinematic scheme of the drive is shown in Fig. 2.

The drive of the brush rotor in rotation with a frequency of $n_{p}=325 \mathrm{rpm}$ is carried out from an electric motor with a synchronous frequency of the rotor $\mathrm{n}_{\text {с.дв }}=$ $1000 \mathrm{rpm}$ using a V-belt transmission. To regulate the center-to-center distance of this transmission, a hinged swinging sub-motor plate with tension bolts was used. The brush rollers are driven from the brush rotor shaft. For this, there are two chain drives located to the right and left of the rotor - three rollers are driven on each side. The odd rollers are driven by a chain drive, which, relative to the central drive sprocket, works with the outside, and even ones with the inside. This ensures the required direction of rotation of the rollers: rollers No. 1, 3 and 5 rotate opposite the direction of rotation of the brush rotor, and rollers No. 2, 4 and 6 in the same direction as the rotor. Both chain drives are tensioned by springloaded pressure wheels. Adjustment of the size of the working gap between the surfaces of the brush rotor and the brush rollers, according to the kinematic diagram, is carried out by simultaneous movement of all six rollers in the radial direction relative to the center of the rotor. The sliding bearings of the roller axles sit in the radial grooves of the fixed sidewalls. The length of the grooves corresponds to the stipulated adjustment interval for the size of the working gap, taking into account the limits of the permissible value of brush wear. At the same time, the axes of the rollers pass through the inclined grooves in the overhead swivel plates (cheeks), which have the ability to return relative to the sidewalls. For this, there are cylindrical protrusions on the inner sides of the sidewalls, coaxial with the longitudinal axis of the rotor. Toothed segments are attached to the overhead cheek plates, which mesh with two gears. The gears are attached to the ends of the auxiliary shaft parallel to the rotor axis. The shaft is turned manually through a worm gear with a flywheel and a pointer arrow, which interacts 

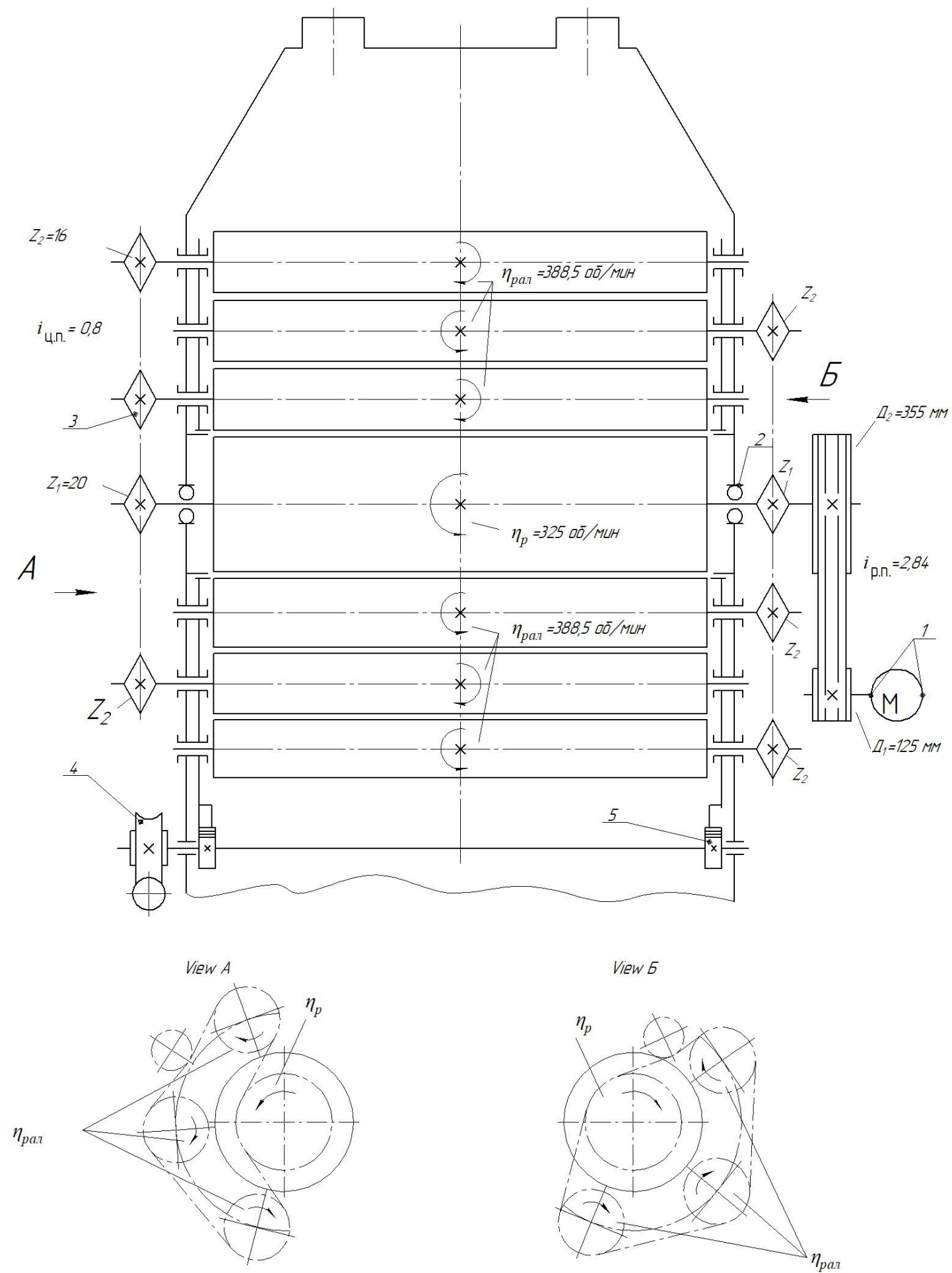

View 5

Fig. 2. Kinematic scheme of the drive of the improved brush machine

with a stationary dial scale. The features of the functioning and calculation of the regulating device are shown in Fig. 3, containing a functional scheme of the device (Fig. 3, a) and its design scheme (Fig. 3, b).

The drive of the brush rotor in rotation with a frequency of $n_{p}=325 \mathrm{rpm}$ is carried out from an electric motor with a synchronous frequency of the rotor $\mathrm{n}_{\text {с.дв }}=$ $1000 \mathrm{rpm}$ using a V-belt transmission. To regulate the center-to-center distance of this transmission, a hinged swinging sub-motor plate with tension bolts was used. The brush rollers are driven from the brush rotor shaft. For this, there are two chain drives located to the right and left of the rotor - three rollers are driven on each side. The odd rollers are driven by a chain drive, which, relative to the central drive sprocket, works with the outside, and even ones with the inside. This ensures the required direction of rotation of the rollers: rollers No. 1, 3 and 5 rotate opposite the direction of rotation of the brush rotor, and rollers No. 2, 4 and 6 in the same direction as the rotor. Both chain drives are tensioned by springloaded pressure wheels. Adjustment of the size of the working gap between the surfaces of the brush rotor and the brush rollers, according to the kinematic diagram, is carried out by simultaneous movement of all six rollers in the radial direction relative to the center of the rotor. The sliding bearings of the roller axles sit in the radial 
grooves of the fixed sidewalls. The length of the grooves corresponds to the stipulated adjustment interval for the size of the working gap, taking into account the limits of the permissible value of brush wear. At the same time, the axes of the rollers pass through the inclined grooves in the overhead swivel plates (cheeks), which have the ability to return relative to the sidewalls. For this, there are cylindrical protrusions on the inner sides of the sidewalls, coaxial with the longitudinal axis of the rotor. Toothed segments are attached to the overhead cheek plates, which mesh with two gears. The gears are attached to the ends of the auxiliary shaft parallel to the rotor axis. The shaft is turned manually through a worm gear with a flywheel and a pointer arrow, which interacts with a stationary dial scale. The features of the functioning and calculation of the regulating device are shown in Fig. 3, containing a functional scheme of the device (Fig. 3, a) and its design scheme (Fig. 3, b).

The scheme shows: 1 fixed sidewall; 2-radial groove; 3-swivel cheek plate; 4-sloped slot in the return plate; 5 -axis of the brush roller in the extreme (close to the center) position - point $\mathrm{O}_{1}$. Point $\mathrm{O}_{2}$ shows such a position of the swivel cheek plate when the axis 5 is at the maximum distance from the center. The rotation of the cheek 3 in the direction of the arrow $\mathrm{C}$ (in the diagram) leads to a radial displacement of the axis of the roller 5 from point 5 to point $\mathrm{O}_{1}$, which in the extreme position is aligned with point $\mathrm{O}_{2}$. For this, the cheek 3 must turn through a certain angle $\beta$. Let us denote the lateral plane of the groove 4 by the letters A - A. The point of contact of the axis of the brush roller 5 with the plane A-A is denoted by the letter $\mathrm{A}$. The lateral plane of the radial

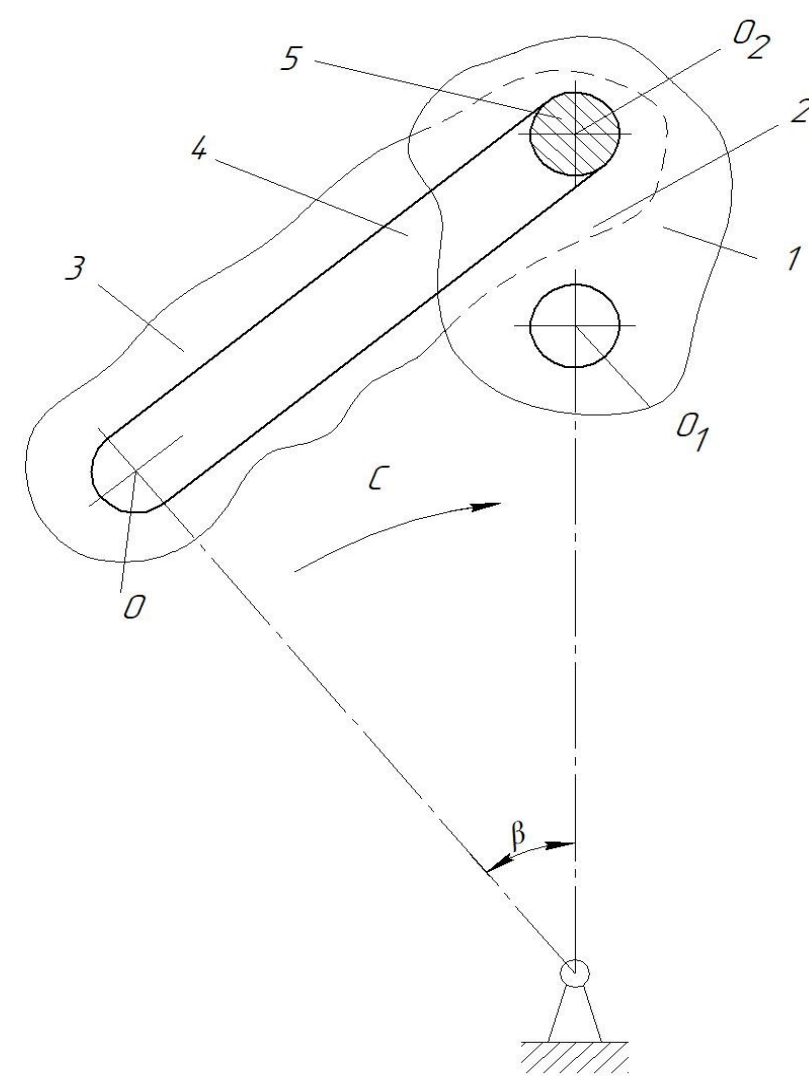

Fig. 3,a. Functional scheme of the device for adjusting the size of the working gap: 1 - sidewall irregularity; 2 - radial groove; 3 rotary cheeks; 4 - inclined groove in the cheek $3 ; 5$ - brush roller in the extreme position, close to the center - point $O_{1}$.

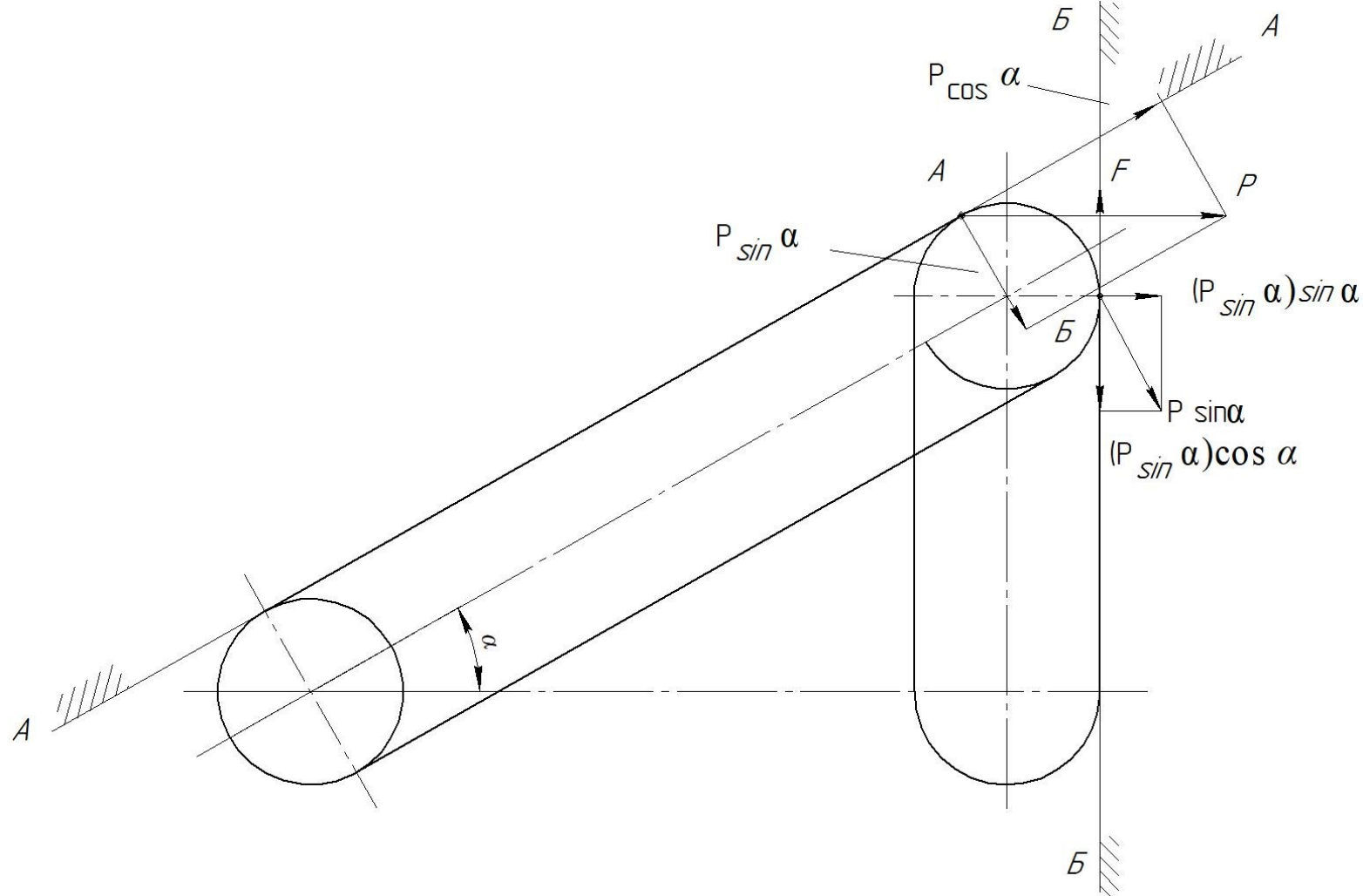

Fig. 3, b. Design scheme of the device for adjusting the size of the working gap:

A-A - side plane of the groove A-A; Б-Б - side plane the radial groove of the fixed sidewall; 5 - the point of contact of the plane $5-5$ with the roller axis; $P$ is the force with which the surface of the cheek 3 acts on the roller axis at point $A ; \alpha$ is the angle of inclination to the horizon of the longitudinal axis of the groove 4 ; $F$ is the friction force between the axis 5 of the brush roller and plane $5-5$. 


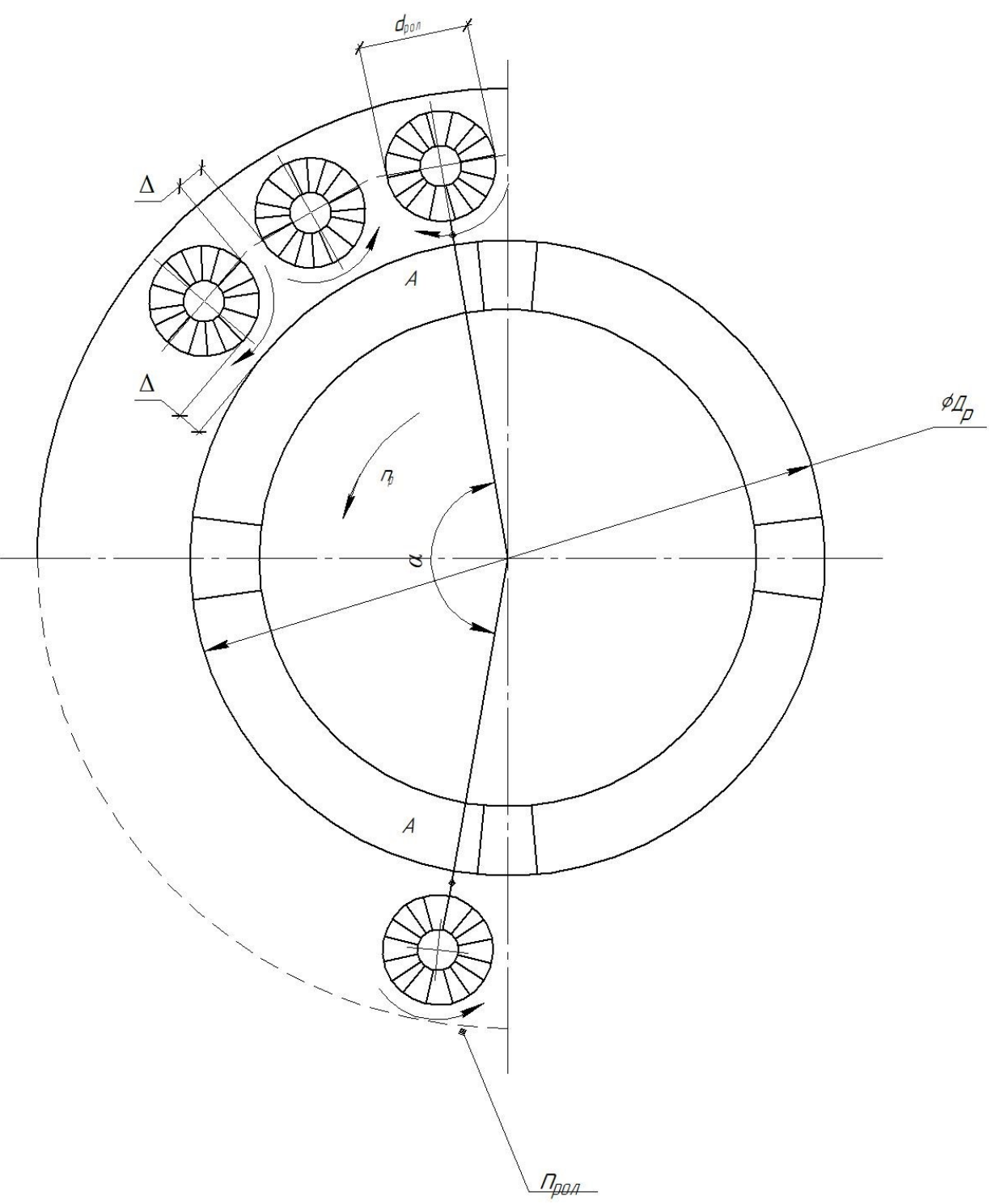

Fig. 4. Design scheme for determining the diameter of the brush rollers $d_{\mathrm{pon}}$ - roller diameter;

Др - the diameter of the brush rotor; $\Delta$ is the gap between the brush surfaces of the rotor and the rollers; $\alpha$ is the central angle of the arc A-A; np and nрол - rotor and roller speed

groove of the fixed sidewall is denoted by Б- $Б$, and the point of its contact with the roller axis - by the letter $\mathrm{B}$. When the cheek is turned in the direction of arrow $C$, it acts on the roller axis by a conventionally horizontal force $\mathrm{P}$ applied at the point of contact A. If the angle of inclination of the longitudinal the axis of the slot 4 to the horizon is designated $\alpha$, then the components of the force $\mathrm{P}$ can be designated Psin $\alpha$ and $\mathrm{P} \cos \alpha$. The component Psin $\alpha$ applied to the plane Б-Б at point Б. Its components are shown in the diagram in Fig. 3, 6: radial $P \sin \alpha \cdot \cos \alpha$ and normal Psin $\alpha \cdot \sin \alpha$. The radial component, overcoming the friction force $\mathrm{F}$, leads to the displacement of the roller axis along the plane Б-Б. The condition of this displacement is $P \sin \alpha \cdot \cos \alpha>F$. Since $F=f \cdot P$, and the coefficient of friction $\mathrm{f}=\tan \varphi$, where $\varphi$ is the angle of friction of the axis along the plane $\mathrm{Б}-\mathrm{5}$, then after transformations, we obtain the condition for the sliding of the axis 5 along the surface $\mathrm{Б}$ - $\mathrm{\text {in }}$ the form

$$
\alpha<90^{\circ}-\varphi \text {. }
$$

Determination of the diameter of the brush roller $d_{\text {рол }}$ is carried out according to Fig. 4. The length of the arc A A corresponding to the central angle $\alpha$ is equal to

$$
\mathrm{L}_{\mathrm{A}-\mathrm{A}}=\pi \cdot Д_{\text {роб }} \frac{\pi}{\mathrm{a} \sigma \mathrm{o}}, \mathrm{mm} \text {, }
$$

where $Д_{\text {роб }}$ are the diameter of the circle of the centers of the rollers $Д_{\text {роб }}=\mathrm{d}_{\text {рол }}+2 \Delta+Д_{\mathrm{p}}$, mm. But, on the other hand,

$$
\mathrm{L}_{\mathrm{A}-\mathrm{A}}=(\mathrm{Z}-1)\left(\mathrm{d}_{\text {рол }}+\Delta\right), \mathrm{mm} \text {. }
$$

If we equate the right-hand sides of expressions (4) and (5), we get the equation

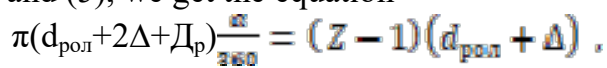

where $Z=6$ - the number of brush rollers, taken constructively.

Since $\alpha=172^{\circ}$, then after transformations, we get $\mathrm{d}_{\text {рол }} \cong 152 \mathrm{~mm}$.

\section{Conclusions}

Thus, based on the proposal of the invention No. 459248 , it is possible by calculation to determine the design and kinematic parameters of the brush-roller deck, which is advisable to use in the improved brushing machine А1-БЩМ-12. 


\section{REFERENCES}

1. Merko I. T., Morgun V.O. Science fundamentals and technology of grain processing. -Odesa: Druk, 2001.-348s.

2. Gaponyuk O. I. , Soldatenko L.S., Grosul L.G. and insh. Technological possession of grass-growing and cereal farms. Kherson: Oldi-Plus, 2018.-752 p.

3. Soldatenko L.S., Georgi N.V., Kravchenko G.K. Brushing machine for cleaning the grain surface. Author's witness No. 459248.

Л.С. Солдатенко, канд. техн. наук, доцент, E-mail: leonid541247@gmail.com

А.І. Шипко, аспірант, E-mail: shipko.arkadiy@gmail.com

I.М. Шипко, канд. техн. наук, доцент, E-mail: shipkoigor@gmail.com

Одеська національна академія харчових технологій, вул. Канатна, 112, Одеса, 65039, Украина, +380487124113 УДОСКОНАЛЕННЯ КОНСТРУКЦЇ̈ ЩІТКОВОЇ МАШИНИ ДЛЯ ЗЕРНА

\section{Анотація}

Якість готової продукиії мукомельних заводів значною мірою залежить від ефективності зерноочисного обладнання, зокрема, від призначеного для очищення поверхні зерна від щүільних покладів органічного і мінерального пилу. В сучасних умовах гострого дефіцииту господарсько-питної води, коли застосування мийних $і$ мийно-лущильних машин стає недоцільним або зовсім неможливим, значно підсилюється роль обладнання для сухої обробки поверхні зерна - оббивальних $i$ щіткових машин. Оббивальні машини відокремлюють від поверхні зерна високозольні пилові відкладення, відокремлюють зародок і чубок, руйнують грудки землі, співрозмірні з зерном, а також призводять до часткового лущення плодових оболонок. Але вони неспроможні вилучити пил і мікроорганізми з борозенки зернівок. Цю задачу - за відсутності мийних і мийно-лущильних машин - вирімують виключно щиіткові машини. Вони вилучають пил і мікроорганізми з борозенки, залишки пилу, зародка і чубка, надірвані оббивальними машинами плодові оболонки $і$ зменшують зольність очищеного зерна на 0,02 ...0,03\%. І хоча ефективність щуіткових машин менша за ефективність оббивальних, на завершальних етапах очищення поверхні зерна вони незамінні. Визначальний вплив на ефективність дії щіткових машин створює технічний стан робочих органів і величина робочого зазора між щітковим ротором і щітковою декою, яка повинна дорівнювати 4...8 мм. Однак, з часом щіткові поверхні ротора і деки зношуються, забруднюються, забиваються пилом і деформуються - щетина отримує ухил, і робочий зазор збільшується. Певною мірою це корегують иляхом регулювання спеціальним регулювальним механізмом. Але його можливості обмежені, до того ж, чим далі, тим частіше і менш ефективніше стає регулювання. Удосконаленням щіткових машин займаються фахівиі багатьох краӥн: Росії, Швейцарії, Польщі і ін. Огляд конструкцій $i$ функиіональних схем машин різних фірм, а також винаходів і патентів у иій галузі, може сприяти удосконаленню щүіткової машини А1-БЩМ-12, яку найчастіше застосовують у потокових лініях вітчизняних підприємств.

Винахід «Щіткова машина для очищення поверхні зерна» за автор. свід. №459248 якраз і стосується обладнання для очищення зерна пшеничі і жита.

Метою винаходу є підвищення ефективності обробки поверхні зерна за рахунок подовження шляху його тертя по робочим поверхням ротора і деки і неперервного вилучення відокремлених від зерна частинок по усій поверхні деки. . Для цъього запропонована машина має деку, яка складається з набора ичиліндричних щціткових роликів, які обертаються у взаємно протилежних напрямках. Зовні деку охоплює ситова обичайка, яка може бути зроблена гофрованою для збільшення ефекту очищення зерна.

Робоча зона сформована обертальним щчітковим ротором і щітково-роликовою декою. Ролики непарних номерів обертаються у напрямку, протилежнім напрямку обертання ротора, зі швидкістю вдвічі меншою, а ролики парних номерів з такою же швидкістю, як і непарні, але в той же бік, що і ротор. Зерно в робочій зоні проходить складний зігзагоподібний шлях, після чого продувається повітрям і виходить назовні. Для компенсаиії зносу щіток і регулювання величини робочого зазора, осі роликів з обох боків встановлені в радіальних пазах двох нерухомих боковин $і$ одночасно в похилих пазах поворотних пластин, встановлених на ииліндричних виступах цих боковин. Оскільки сумарна площа поверхні щиіткових роликів майже в 4 рази перевищує площу деки машини БЩМ-12, то питоме навантаження поверхні роликів значно зменшується, щзо гарантує більи тривалу і ефективну роботу щзіткової машини.

Ключові слова: щіткова машина для зерна; зольність зерна; борозенка; щүітковий ротор; щіткові ролики; робочий зазор.

\section{ЛІТЕРАТУРА}

1. Мерко І. Т. , Моргун В. О. Наукові основи і технологія переробки зерна. -Одеса: Друк, 2001. -348с.

2. Гапонюк О. І. , Солдатенко Л. С., Гросул Л. Г. та інш. Технологічне обладнання борошномельних $і$ круп'яних підприсмств. -Херсон: Олді-Плюс, 2018. -752 с.

3. Солдатенко Л.С., Георги Н.В., Кравченко Г.К. Щеточная машина для очистки поверхности зерна. Авт. свид. № 459248 .

Received 27.04.2020

Reviewed 15.05.2020

Revised $\quad 06.08 .2020$

Approved 28.08.2020

Cite as Vancouver Citation Style

Soldatenko L., Shipko A., Shipko I. Improving the design of the brush machine for grai. Grain Products and Mixed Fodder's, 2020; 20 (3, 79): 47-50. DOI https://doi.org/10.15673

Cite as State Standard of Ukraine 8302:2015

Improving the design of the brush machine for grai / Soldatenko L. et al. // Grain Products and Mixed Fodder's. 2020. Vol. 20, Issue 3 (79). P. 47-50. DOI https://doi.org/10.15673

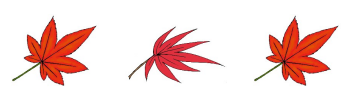

